\title{
Orra White Hitchcock: A Virtuous Woman Theresa Marche
}

As an artist and teacher, Orra White Hitchcock initiated major changes in her school's art program for young ladies. Her interests joined the two disciplines of art and science, and she was among the earliest published female scientific illustrators in this country. Much of her life was devoted to raising six children, keeping her home and serving the needs of her husband. In this, she would seem to be a perfect example of the subservience of female accomplishment to male initiative as was the ideal in Victorian times. But a closer look will reveal that this was not completely true and that she actually countered many stereotyped conventions of that period. ${ }^{1}$

Orra White was born on 8 March 1796, in South Amherst, Massachusetts. The only surviving daughter of Jarib White, "a farmer of easy circumstances," (Tyler, 1863, p. 3) she seems to have become his favorite child, despite having three brothers. ${ }^{2}$ Because her father believed firmly in education for women as well as for men, he hired a gentleman tutor (identity unknown) for his daughter, and until about age ten she studied at home (Worman, 1989).

She began at an early age to draw and paint, producing by age seven an "endless knot" in pen and ink, "with little figures of birds and flowers in the openings of the knot and as a border" (M. R. Hitchcock, 1937, p. 191). She also created some paintings in color, including landscapes, flower pieces, and imaginary views when she was about eleven. ${ }^{3}$

Sometime between 1806 and 1811 she was sent to South Hadley, Massachusetts to attend the boarding school of "the Misses Wright." 4 Later she went to "the then famous school of Roxbury" 5 and became proficient in Latin, Greek and the natural sciences, including astronomy and mathematics (Tyler, 1863). She was allowed, even encouraged to pursue subjects that have to this day been largely reserved for males and her competence went beyond the mere dabbling deemed sufficient for most females of the time.

A drawing book survives from this period, bearing an inscription on the cover in her handwriting, "Orra L. White, Boston" (Worman, 1989). It contains many drawings of "views" and flowers, subjects that presaged her later interests (M. R. Hitchcock, 1937). Her mathematics notebook includes chronological problems, methods of computing the moon's longitude and determining syzygies, the alignment of earth, moon and sun necessary for both solar and lunar eclipses. (White, 1810). Though a product of her early 
schooling, this notebook probably proved useful in her later teaching of both mathematics and astronomy.

In the back of this same volume are found eight handwritten pages entitled "Eloquence" that may provide insight into Orra's developing values and ideals. They are an excerpt from "Curran's speeches" and were possibly intended to be memorized or delivered as an exercise. This quotation begins by questioning the treatment of wives, raising "the inevitable consequences of thus treating them like slaves" (White, 1810) Next is an exposition of the effects of adultery on each member of a family, and ends with a call for the adulterer to stop and consider the results before acting. In all, the selection reaffirms the sanctity of family, home, and the mother's place within it.

Upon completing her education, Orra did not follow the usual custom of returning to her father's house until a suitable match could be made. She instead chose a career, and in 1813 took a position as assistant teacher at Deerfield Academy, some ten miles north of her home. (Tyler, 1863) There she taught both the exact sciences and the fine arts to female students.

In the Victorian period, female education was aimed at preparing ladies to be "obedient daughters, faithful wives and prudent mothers; to be useful in the affairs of a house; to be sensible companions and affectionate friends" (Flynt, 1988, p. 12). To be considered an educated woman, mastery of the basics was required; to be considered a lady, mastery of the ornamental accomplishments was also essential.

Ornamental accomplishments in the earliest years at Deerfield involved learning to create embroidery, especially mourning embroidery. Illustrations from literature, family coats of arms, and elaborate allegorical scenes were painted on silk or linen and then stitched with silk thread. Lessons in this skill required an extra payment of twenty five cents, with the charge for framing often amounting to more than a school term's ${ }^{6}$ entire tuition (Flynt, 1988).

With Orra White's arrival, this emphasis on embroidery changed dramatically. Under her tutelage, drawing and painting, in ink and watercolor, as well as map making were elevated to front rank. Subjects were derived from popular literature, prints of romantic English landscapes, as well as motifs of flowers and shells. Decorative wooden boxes were painted by her students, as well as hand fire screens used by ladies of the day to shield their faces from direct fireplace heat. "Extant paintings and drawings by Orra White's pupils form the largest body of artwork produced during the first quarter of the nineteenth century at Deerfield Academy" (Flynt, 1988, p. 32.)

Orra continued her own artwork at this time, copying portraits and landscapes from published works. Perhaps as an aid for her teaching of botany, she compiled, in 1818 , the "Herbarium, parvum, pictum" that contains fifty illustrations in watercolor, half being grasses and the other half flowers

\section{Working Papers in Art Education 1991}


(Worman, 1989). All the paintings were done from life, using specimens collected and identified by Edward Hitchcock. When these plants were later completely destroyed by insects, Orra's paintings became a unique and valuable pictorial record. Although the "Herbarium" was never published, it was sent many years later to Professor Asa Gray of Harvard for verification of the names and his pencilled notes remain in the text.

The Young Ladies Literary Society had its beginnings at Deerfield Academy in 1813, the same year as Orra's arrival. It is probable, but not certain, that she had some part in its founding. She was a charter member and one of the signers of the Society's constitution. With the goal of attaining moral excellence, the members studied science and literature to "enlighten, expand, and embellish the mind, to cultivate and purify the heart" (Sheldon, 1896, p. 827).

During her years at Deerfield, Orra not only completely realigned the arts program for young ladies, but she also modeled an interdisciplinary relationship between the arts and sciences that is becoming so much a part of modern educational discourse. By the time she first met her future husband, Edward Hitchcock, Orra was an independent, self-supporting professional in an academic world.

Between Orra White and Edward Hitchcock there seems to have been an immediate attraction and they developed a relationship of mutual respect, interest, and affection. They first met sometime between 1813 and December of 1814. At that time, Hitchcock was recovering from a serious illness that had affected his eyesight and which also changed the course of his life. As an outlet during his convalescence, he had written a poetic drama of about 500 lines entitled, The Emancipation of Europe, or the Downfall of Bonaparte: A Tragedy which was published in 1815 . When the drama was performed, Edward cast himself in the leading male role as Alexander, Emperor of Russia. His leading lady, ${ }^{8}$ in the part of Maria Louisa, Empress of France, was played by Orra White (Worman, 1989). In his Reminiscences of Amherst College, Hitchcock recalls that the play "was loudly called for by the rural population before whom it was acted with much success" (E. Hitchcock, 1863, p. 388).

In 1816, Edward took the position of Preceptor at Deerfield Academy. It is highly probable that Orra encouraged him in this and also possible that she even exerted influence on his behalf at the Academy. Attaining this position marked the end of a very difficult period in Edward's life that saw, among other things, the end of his dream for a career in astronomy. Many years later, in the dedication to his Religion of Geology, Edward acknowledged his debt to Orra:

Early should I have sunk under the pressure of feeble health, nervous despondancy, poverty and blighted hopes, had not your sympathy and cheering counsels sustained me. (E. Hitchcock, 1851, p. iii) 
Orra and Edward found opportunities to be together, not only at the Academy and in mutual scientific pursuits, but also in those means that have been used by young people for ages. One note from Edward has survived:

Do you think Orra, if you would go up to Harriet's toward night we could make it so muddy, dark and rainy this evening that it would be impossible for you to get back tonight? If such should be your belief I avow [?] you I should be very happy to be placed in the same predicament (after Mr. Eliphalet and wife have gone to bed) or in other words "I'll be with you bye and bye.' E. (E. Hitchcock, 1816-?)

Shared excursions for the study of geology and botany took Orra and Edward into the Connecticut River Valley. Of one such trip, Hitchcock wrote, "From this spot a view of these falls was taken in 1818, by a friend" (Worman, 1989, p. 652). Their visit resulted in Orra's first known published art work, "Falls on Connecticut River, at Gill, Mass." printed in The Port Folio, December, 1818 and accompanied by a descriptive note signed "E. H." (M. R. Hitchcock, 1937)

Sometime during 1818 , Orra left Deerfield to return to Amherst, her hometown, to take the position of Preceptress at Amherst Academy. Although she taught there only one year, it was long enough to begin a lifelong friendship with Mary Lyon, a student in chemistry. Lyon was a "large strong country girl, careless of dress and manner, but with a superior intellect and an absolute passion for learning" (Worman, 1989, p. 654) who later went on to found Mount Holyoke Female Seminary (now Mount Holyoke College). Lyon would later study science under Edward and learn drawing and painting from Orra. In 1838, Orra produced the designs for the Great Seal of Mount Holyoke and for a vignette to appear at the top of this college's diplomas (Worman, 1989).

Edward remained at Deerfield Academy until 1819 when the institution was forced to close temporarily for financial reasons. By that time he had received an honorary A. M. degree from Yale (E. Hitchcock, 1818) and had begun to study for the ministry.

On 31 May 1821 Orra and Edward were married in a tavern in Amherst. Three weeks later, Edward was ordained as a minister before taking charge of the parish of Conway, a small rural community fifteen miles northwest of Amherst (Worman, 1989).

Orra's decision to marry carried with it the same choice between family and career that has been an issue for women to this day. Following the tenants of her Orthodox faith, Orra elected to give up her career and become a dutiful wife, a decision that would seem to be inviting mental and psychological suffocation. Her survival was probably due to her refusal to become isolated within her home and her abhorrence of idleness $(\mathrm{O} . \mathrm{W}$.

\section{Working Papers in Art Education 1991}


Hitchcock, 1847). There was also the continuing dialogue with Edward on matters of science, mathematics, theology, and teaching as he pursued his various researches. ${ }^{9}$ Orra's contribution to this dialogue did not go unnoticed or unappreciated:

March 30th 1840 the greatest temporal blessing which I have ever received from the hand of God was in permitting me to be allied to such a woman as my wife has proved to be. I feel quite sure that had it not been for her friendship previous to marriage I never should have surmounted the difficulties in my way. And since our marriage she has been everything to me that I could expect of any mortal. (E. Hitchcock, 1829, p. 63)

Orra's attempt to fill her new role as a pastor's wife was made more difficult by the death of their first child and separation from the academic life the couple had previously known. Edward compensated by immersing himself in scientific work and excursions. A true intellectual, he seemed ill suited to the calling of parish minister. Orra seems to have adapted better. Despite the loss of her own career, she involved herself socially in the community A model of refinement in a small rural town, she taught the young ladies, elevating their tastes, without giving the "least impression of conscious superiority" (Tyler, 1863, p. 5).

She also continued with her art, and in 1821, filled a sketchbook with watercolor drawings of mushrooms. Entitled "Fungi selecti picti," its twenty pages each contained from one to a dozen specimens, numbered and named in Orra's handwriting (Tyler, 1863). Her only known oil painting, of the first building at Amherst College, was also done in this period. A series of prints illustrating her husband's publications appeared at this time (1823) and included drawings by Orra of fossil fish and plants (Worman, 1989).

After four years, Edward requested a release from his charge at Conway, pleading exhaustion, and in October, 1825 gave up the congregational ministry (Worman, 1989). The Hitchcocks next took up residence in Amherst, where Edward had been appointed Professor of Chemistry and Natural History at the newly founded Amherst College. This situation proved so suitable for the Hitchcocks that they remained there the rest of their lives. Edward eventually became President of the College while Orra's presence was felt in numerous ways, academic, social and religious: "It should be recorded that Mrs. Hitchcock, by holding a reception every two weeks for the undergraduates and opening her house on Monday evenings for prayer meetings, was a genuine cultural force in the community" (Fuess, 1935, p. 147. Her skills in art were well known and esteemed by the students who, after graduating, sent sketches from distant places for her criticism (M. R. Hitchcock, 1937).

During this time, Edward frequently turned to Orra for illustrations of his many scientific works, which led to a completely different outlet for 
her artistic skills. Perhaps most important was the Report on the Geology, Mineralogy, Botany, and Zoology of Massachusetts (E. Hitchcock, 1833), prepared while Edward held the appointment of State Geologist. A monumental work that was later re-published twice, it was for the most part, illustrated by Orra. These sketches include a set of nine landscape plates of scenes from the Connecticut River Valley signed, "Mrs. Hitchcock del[ineavit]." 'Anonymous' was not a label that this woman used. While these landscapes comprise the most famous part of her published work, it has been noted of them that "Although intended as scientific illustrations, Orra Hitchcock's prints are more picturesque than topographically accurate" (Flynt, 1990, p. 10). For instance, the "Gorge Between Holyoke and Tom" became much narrower in her hands to permit a larger scale rending of the mountains, and the "View of Sugarloaf Mountain" shows the more dramatic eastern rock face superimposed on the western side.

Another landscape drawn by Orra for this volume is one labeled "West View from Holyoke." It was first lithographed in 1833, but was probably drawn a year or two earlier. This print bears a striking resemblance to an oil painting by Thomas Cole entitled "The Oxbow" (The Connecticut River near Northampton, 1836). There is good cause for the similarity; both artists were working from the same vantage point. Though the location is unmistakable, the treatment of it by each artist is quite different.

In Orra's drawing, the oxbow is pushed so far to one side that it had to be distorted in order to fit on the page. Her river flows through a pastoral landscape of neat farms surrounding the village of Northampton. Inclusion of this village was so important to Orra that she placed it much closer to the oxbow just to fit it in. By rendering the various buildings at a relatively large size, she reduces the strength of the river by comparison. A few fluffy clouds drift in a bright summer sky. This is a peaceful scene of ordered calm.

Cole's version, on the other hand, seeths with action. He has placed the oxbow near the center of his canvas and then cut off a portion by overlapping the high cliff of Mt. Holyoke in front of it. This give the feeling of deep space to the composition. While he does show the land marked off in fields, one must look closely to find any buildings at all. Those that do appear are depicted so small that the river becomes impressive by comparison. Meanwhile, the trees on the mountain are swirling in the fury of an oncoming thunderstorm.

Where Orra has chosen to portray serene order, Cole has painted a turbulent wilderness. One might be inclined to argue that this reveals some type of feminine sentiment as opposed to a masculine power. However, it might be closer to the truth to remember that Cole was born and raised in England. Unlike most Americans of the day, including Orra, who regarded the wilderness as a force to be battled with and pushed back, Europeans had a tendency to revel in the very wildness so long vanished from their native lands. Also, Cole had been trained in the Romantic style of painting then

Working Papers in Art Education 1991 
prevalent in Europe, and this painting was done specifically to appeal to that popular taste. Orra's scene depicts the triumph of order (good) over the uncontrolled wilderness (evil). Cole portrays the Romantic ideal of the primal wilderness as good in itself, until marred by human hands.

Orra also produced numerous plates of specimen illustrations for the Report on the Geology, Mineralogy, Botany, and Zoology of

Massachusetts, and in these her rendering is scientifically accurate. Even today, her illustrations have proven critical to identification of individual specimens in Edward's geological collections (Marche', in press). By her husband's count, Orra had, over the course of her lifetime, created the greatest part of the "232 plates and 1134 woodcuts" in his works.

Along with her published works, Orra produced a vast number of drawings and paintings for Edward's use in the classroom, some of which were quite large ${ }^{10}$ (Flynt, 1990). One life-sized drawing of an Iguanodon was said to be 70 feet long. About 60 paintings on cloth, some as much as eight feet long, depicted various geological subjects, while another 11 showed fossil skeletons or footprints (Worman, 1989).

The dedication to Edward's Religion in Geology presents a moving tribute to Orra as the wife and friend who had so greatly influenced the course of his life. There he gave full credit for her artistic accomplishments:

Furthermore, while I have described scientific facts with the pen, how much more vividly have they been portrayed by your pencil! And it is particularly appropriate that your name should be associated with mine in any effort where the theme is geology; since your artistic skill has done more than my voice to render that science attractive to the young men whom I have instructed. (E. Hitchcock, 1851, p. iii)

Orra's production of artwork continued at least until 1850, when two allegorical landscapes were prepared for a book by her husband on phenomena of the four seasons. Another volume was a biography Edward prepared of their good friend the late Mary Lyon (E. Hitchcock, 1855). It contains four illustrations. One of them, a portrait of Mary, is drawn in Orra's style and may have been done by her. If so, then it would appear to be her last known published work (Worman, 1989).

In 1855 , at the age of sixty, Orra suffered a fall from a high piazza onto a brick pavement, from which she never fully recovered. Despite progressive weakness and poor eyesight, she tried to remain as active as possible, but was unable to continue with her art. When a cold turned into pneumonia late in May, 1863, she died surrounded by friends, family and a husband who had always expected that their fates would be reversed and he would die first (Tyler, 1863). 
As a teacher, Orra White Hitchcock completely re-directed the course of the arts for young ladies at Deerfield Academy. Bringing together science and art both in her teaching and in the illustrations that gained her public recognition, she was able to excel in the public sphere as a scholar, teacher, artist, friend and confidant of those who moved among the highest circles of academic life at Amherst. She displayed strength, intelligence and talent in an era that valued very different female virtues. But Orra carried herself with such refinement and grace that she won the esteem and admiration of all who knew her.

Good common sense, and the perfect balance of all her faculties, laid the foundation of her usefulness. Those who know her most intimately have often remarked that they never knew such repose and quietness united with so much energy and efficiency. No one... will say that she wanted any of the principal features of the 'virtuous woman'. (Tyler, 1863, p. 11)

\section{Footnotes}

1. In researching the life of Orra White Hitchcock, one find few primary sources. Other than her sketch books, art work, and one mathematics notebook, Orra left very little record of her life. Her only known written works are three diaries from her trips to Richmond, VA in 1847 and Europe in 1850. These are now part of the President Hitchcock Papers in the Special Collections/Archives of Amherst College Library. The single best account of Orra's life is to be found in the biographical sketch given at her funeral, and later published by the Reverend William S. Tyler, a close family friend. Edward's personal papers and other published works are also essential for insights into Orra's married life.

Eugene Worman has written the most complete modern account that focuses on Orra's life and published works. Conversations with him and with Tina Cohen, Archivist at Deerfield Academy, were invaluable in preparing this paper. Two recent publications by Suzanne Flynt give insight into the history and operation of Deerfield Academy.

Visits to some of the locations in Massachusetts rendered by Orra gave this writer a clearer sense of her approach to illustration.

2. Only one brother survived beyond early manhood and he later became estranged from the family (Tyler, 1863).

3. These early childhood works are reportedly still owned by her great-granddaughter's family (Worman, 1989).

4. The "Misses Wright" were actually Miss Abigail Wright and her half-sister Sophia Goodrich (Worman, 1989).

Working Papers in Art Education 1991 
5. For all its fame, the name of this school is never mentioned, and has been impossible to document (Worman, 1989).

6. The school year was divided into quarters of eleven to twelve weeks, corresponding to the seasons of the year. Students were usually in their teens although some were as young as ten and as old as thirty. They enrolled by the quarter, attending from one to four quarters per year. Summer was by far the most popular quarter for females. It was not unusual for parents at this time to send their daughters to more than one academy (Flynt, 1988).

7. In a note that later accompanied the donation of this work to the Deerfield Academy Archives, Orra's daughter, Emily, stated that the watercolor paintings were done with a fine brush since there were no lead pencils or erasers at that time. (Emily Hitchcock, personal note accompanying the manuscript, date unknown.)

8. Hitchcock was aware of the jealousy among the local ladies over his choice of Orra who was an outsider newly arrived from Amherst. "The girls here will, like Satan, 'look askance with eye malign' because I go out of town for an actor, but thank heaven I have a right to choose whom I please" (M. R. Hitchcock, 1937, p. 191).

9. Her involvement with Edward's studies led her at one point 775 feet deep into the earth as one of the few women of her station to descend into a coal mine. This occurred at the Richmond, Virgina Midlothian Mine in 1847. Her diary details the protective clothing donned in preparation for the descent as well as the ride in a basket lowered from above (O. W. Hitchcock, 1847).

10. Many of these classroom visual aids were displayed for the first time, along with much of the rest of Orra's work, at the Charles P. Russel Gallery, Reed Center for the Arts, Deerfield Academy, April 7 to June 9, 1991.

\section{References}

Fuess, C. M. (1935. Amherst. The story of a New England college. Boston, MA: Little Brown and Company.

Flynt, S. L. (1988). Ornamental and useful accomplishments: Schoolgirl education and Deerfield Academy 1800-1830. Deerfield, MA: Pocumtuck Valley Memorial Association.

Flynt, S. L. (1990). Family, home and place: Nineteenth Century prints. Deerfield, MA: Pocumtuck Valley Memorial Association.

Hitchcock, E. (1815). Emancipation of Europe, or the downfall of Bonaparte: A tragedy. Greenfield, MA: Denio and Phelps. 
Hitchcock, E. (1816-?). Letter to Orra, 6 September. Hitchcock Family Papers. Pocumtuck Valley Memorial Association Library. Box 3 , folder 3.

Hitchcock, E. (1829). MSS. Private notes [diary begun 8 February 1829]. President Hitchcock Papers. Amherst College Archives. Box 20, folder 7 .

Hitchcock, E. (1833). Report on the geology, mineralogy, botany, and zoology of Massachusetts. Amherst, MA: J. S. and C. Adams.

Hitchcock, E. (1851). Religion of geology and its connected sciences. Boston: Philips, Sampson and Company.

Hitchcock, E. (1855). The power of Christian benevolence illustrated in the life and labors of Mary Lyon. Northampton, MA: Hopkins, Bridgeman, and Company.

Hitchcock, E. (1863). Reminiscences of Amherst College. Northampton, VA: Bridgman and Childs.

Hitchcock, M. R. (1937). And there were women too. Amherst Graduates' Quarterly May, 191-194.

Hitchcock, O. W. (1847). MSS. Virginia Diary. President Hitchcock Papers. Amherst College Archives. Box 20, folder 2.

Marche', J. D., II. (in press). Edward Hitchcock, Fucoides, and the icnogenus Scoyenia. Earth Sciences History.

Sheldon, G. (1896). A history of Deerfield, Massachusetts: The times when and the people by whom it was settled, unsettled and resettled. (Vol. 2). Deerfield, MA: n.p.

Tyler, W. S. (1863). A biographical sketch of Orra White Hitchcock, given at her funeral, May 28, 1863. Springfield, MA: Samuel Bowles \& Company.

White, O. (1810). MSS. Mathematics notebook. President Hitchcock Papers. Amherst College Archives. Box 18, folder 7.

Worman, E. C., Jr. (1989). The watercolors and prints of Orra White Hitchcock. A. B. Bookman's Weekly, 83, 646-668. 
Figure 1

"WEST VIEW FROM HOLYOKE"

Pocumtuck Valley Memorial Association,

Memorial Hall Museum, Deerfield, Massachusetts

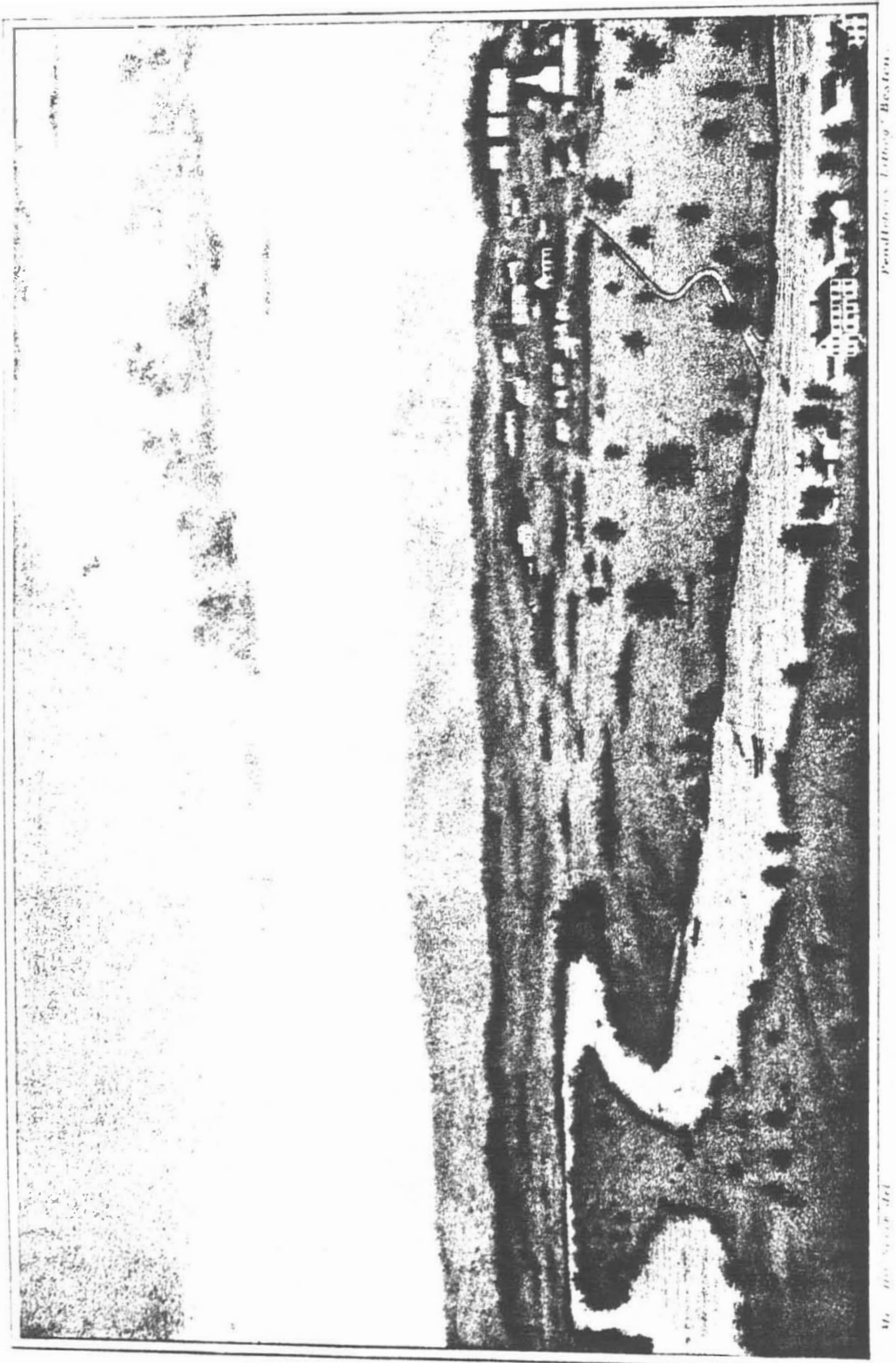




\section{Figure 2}

"THE OXBOW" by Thomas Cole (1801-1848).

The Metropolitan Museum of Art, Gift of Mrs.

Russell Sage, 1908. (08.228) 


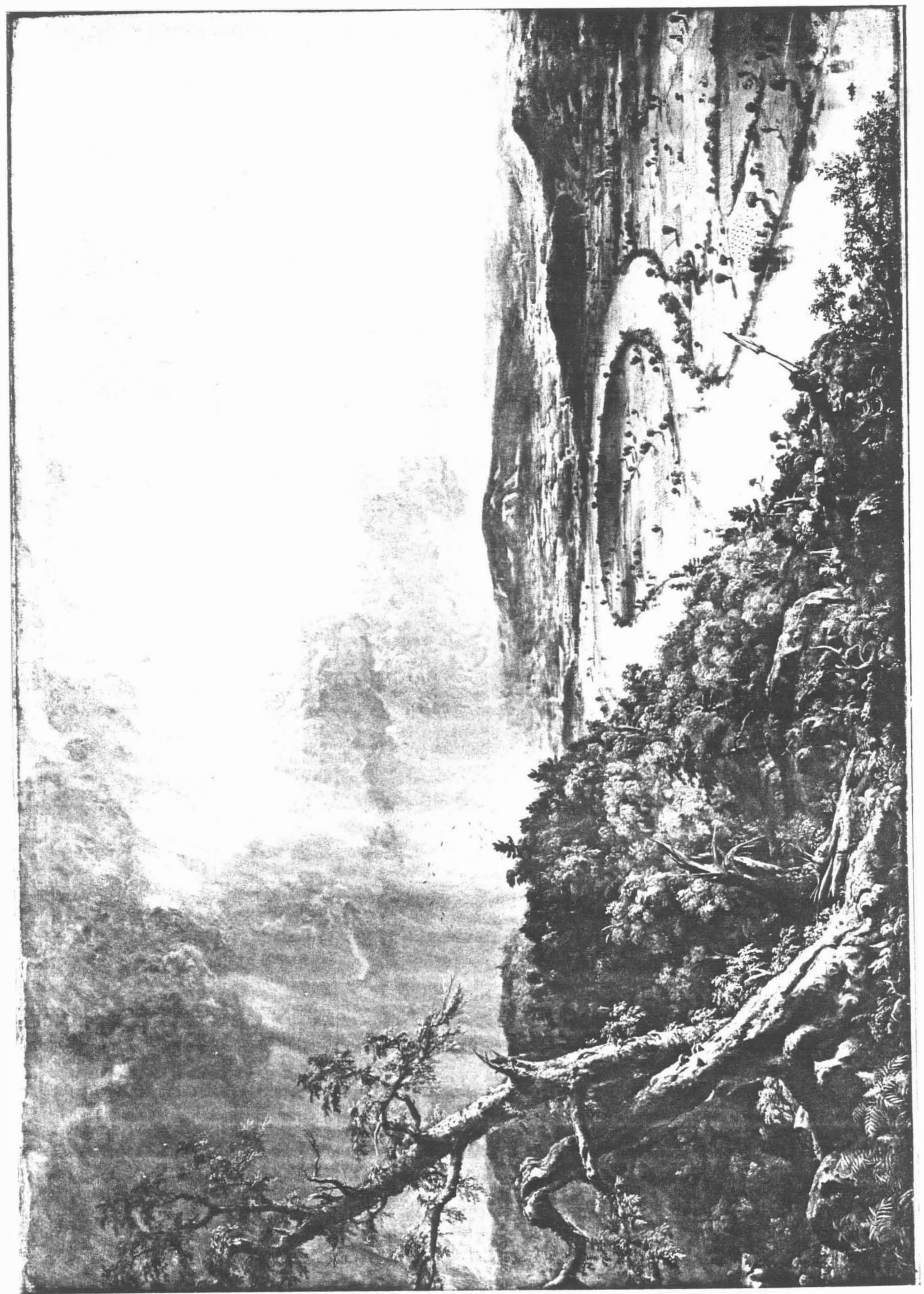

